\title{
Asklepios, Hippocrates and their followers: some aspects of healing and physicians in the Ancient World
}

\author{
E. SAMAMA \\ University of Reims
}

RESUMO: Neste artigo trabalha-se, de uma perspectiva muito geral, com a relação entre a medicina religiosa e as atividades diárias dos médicos no mundo grego, dando-se atenção não somente a alguns dos textos sobre medicina, mas, principalmente, às evidências epigráficas.

PALAVRAS-CHAVE: Medicina grega; fontes epigráficas.

Healing happened in different ways in the Ancient World. In order to understand how the Greeks considered illness and health and what kind of relationship they envisioned between religious medicine on the one hand and physicians, iatroi, on the other, it is necessary to examine some aspects of religious healing and the art of medicine practiced by men and women in the Greek World, paying special attention to their model, the well-known Hippocrates.

In the realm of religious healing, the first figure that must be examined is Asclepios, god of medicine, and patron of all Greek physicians. Legend says that he was born of Princess Koronis and the god Apollo. He was brought up by the Centaur Chiron in the Thessalian mountains. Later versions of the myth state that he was born in Epidaurus and that, after his death, he was honoured as a god. Some sources say that he married Epione (the "mild ") and had six children: two sons Podaliros and Machaon, who are the two physicians mentioned in the Ilias, and four daughters, Akeso, Iaso and Panakeia (she "who heals everything ") and Hygieia, meaning Health. The latter became the most important of his children, she herself becoming the object of a cult. Asklepios is generally represented with a beard and his companion animals are the snake, the cock and the turtle; they symbolize cautiousness and prudence considered to be the main qualities of all physicians.

Asklepios is a "young god" in the Greek pantheon: in Homer's tales he was nothing but the Prince of Tricca in Thessaly and his first mention as a god is to be found during the late fifth century BC. But his sanctuaries grew quickly and became flourishing centers such as Epidaurus where, in honour of the god, a festival of athletic and dramatic contests, the Asklepieia, were held every four years. From Epidaurus, his cult spread to Athens in the last years of the fifth century, to Crete and to Asia Minor (particularily to Pergamon) and finally 
to Rome where he is said to have settled in 292 BC on the Isola Tiberina the Sacred Island, on the Tiber river.

Asklepios is certainly the main, but not the only, healing god. Apollo, who sent the plague, was also supposed to be the only one who could heal that illness and he was worshipped as Apollo Iatros. When Zeus was called upon for help, he was referred to as Zeus Sôter (saviour). Besides these major deities, many heroes were worshipped, such as Telesphoros or Amphiaraios to whom a important sanctuary was dedicated in Oropos, located to the north of Athens not far from Marathon, in a very pleasant and quiet shaded valley watered by a narrow brook.

As the major healing god, Asklepios was honoured in many sanctuaries, called Asklepieia, which all included at least a temple, a sacred spring, a fountain and a dormitory. Archaeologists are still excavating some of these places, such as Cos, Epidaurus and Corinth. Other Asklepieia were built in several big cities, among them, Athens, Pergamon, Eretria, Troezen, Paros, Lebena, Lissos in south Crete and, of course, Rome.

The visit of sick pilgrims to sanctuaries presents a very real interest. The sanctuary, hieron, of Epidaurus serves as an excellent example in point. The pilgrim would first pay a fee to the priests and promise to make an offering to the god if he/she would be cured. After having purified his/her body with the sacred water, the pilgrim would spend the night under the eye of the god. In Epidaurus, as in the other sanctuaries of Asklepios, next to the temple dedicated to the god was a sort of colonnade, the abaton, or dormitory where the sick slept in the hope of experiencing healing dreams during which they might be given advice on a cure and where the harmless sacred snakes crawled over them. The next morning, those who had dreamt of the god would consider themselves to be healed. In order to publicize the power of the god, the priests of Epidaurus, had some of these stories engraved on big steles inside the sanctuary during the second half of the fourth century. These steles served as a form of advertising for the efficiency of their god.

Archaeologists have found three of these steles and the fragment of a fourth on which the stories of seventy of these miracles were engraved. These little stories were very short and almost always written following the same pattern: the patient, whose name and city are indicated, came to implore the god, slept in the abaton, saw the god in his dreams and woke up healthy the next morning. Among them can be read the story of Ambrosia, an Athenian woman (Herzog, n. 4):

"Ambrosia of Athens was blind of one eye. She came to the god to implore him. But walking around the sanctuary, she kept on mocking some of the healings she considered to be incredible and impossible, such as lame or blind men who were healed simply by the vision of the god during their sleep. She laid down in the dormitory and had a vision. It seemed to her that the god stood in front of her, saying that he would heal her, but that she should offer in payment a silver sow in remembrance of her silly attitude; after these words, the god made a small incision in her sick eye and poured in a remedy. When day came, she went away, healed"'. 
The god could even heal at a distance. Heraclotes from Troezen, suffered from an abcess (Peek, n. 48):

"While this man was asleep at Troezen, before being cauterized by the local doctors, he dreamt of the god standing over him urging him not to have the cauterization done, but to sleep in the temple of the Epidaurians. When the time had passed which the god had prescribed, the abcess disappeared and he departed healthy."

Two other texts insist on the revenge of the god who sends the illness back when the patient does not pay what he had promised or what the god - or the priests - had asked for. The following story illustrates this perfectly (Herzog, n. 22):

"Hermon of Thasos. He was blind and the god healed him. After that, as he didn't deliver the fees for the treatment, the god made him blind again. But when he came back (to Epidaurus) and slept (in the dormitory) again, the god healed him once and for all".

All these miracles celebrate Asklepios' power; the god also healed 11 blind, 10 lame and 3 mute people as well as many others from various illnesses. People came from all around the Greek world to consult the god, showing the success of the Asklepieia and of divine healing.

It is most probable that people turned to the god as a last hope, having tried human healers in vain. But it seems that it was not always the case, as indicated by the story of Prepousa who dedicated a stele to the local divinity, Men Axiottenos, in Phrygia, during the Hellenistic period (Varinlioglou, n. 2):

"Because Prepousa [...] had made a vow for her son Philemon, that if he became healthy without wasting money on doctors, she would have it written it on a stone, and although her request had been fulfilled, she did not keep her promise; (therefore) the god now demanded that the promise be kept and punished her father Philemon; she fulfills her vow for her son and from now on, she praises the god."

Prepousa's way of thinking is revealing of the mentality of the time; the cost, the risk, the uncertainty, the discomfort or sheer pain of ancient medical treatment on the one hand and the belief in the omnipotence of the gods on the other explain why people turned to healing deities for help. Prepousa's priority was certainly her son's life, but if she had gone to a doctor, even a famous and expensive one, she could not have been sure that her son would have recovered and she would have wasted her savings. Therefore, making a deal with the god Men Axiottenos seemed more appealing; the god would take his reward only if he succeeded; in the worst case, Prepousa would lose her son, but not her money as well! The success of this sort of miraculous healing lasted throughout the centuries right into the Christian period at which time healing saints took over from the pagan healing gods. 
Within the healing sanctuaries which attracted a lot of sick people, physicians, learned in their art, were also present. They practiced it with skill, and succeeded in saving numerous patients from death! The most famous of these physicians was most certainly Hippocrates, the "Father of medicine", born in Cos, off the Cnidian peninsula, on the Asian coast in 460 $\mathrm{BC}$.

His family on his father Thessalos' side, belonged to the Asclepiads, an aristocratic genos composed of the decendants of Asklepios, the prince of Tricca in Thessaly. Men of this genos were not necessarily physicians, but Hippocrates, his two sons, Thessalos and Dracon, his own father, Thessalos, as well as his grand-father, also named Hippocrates, were. His ancestors had been famous and one of them had helped in the famed Sanctuary of Delphi during the First Sacred War in the sixth century BC. On his mother's side, Hippocrates was, so the ancient biographers say, a descendant of Herakles, thus being twice of noble lineage.

Hippocrates travelled to the north of Greece, to Thessaly, Thracia and Macedonia and practiced his art on the island of Thasos. He also went to Delphi and died in Larissa, in Thessaly, between 375 and 351. After his death, he became the object of a cult as a healing deity.

But Hippocrates was not only a practitioner, he was also a teacher and a writer. $\mathrm{He}$ taught medicine to his sons and, for a salary, to other young men. Those who did not belong to the "genos" of the Asklepiades were supposed to pronounce, before they began their studies, the very famous oath physicians still revere, - though slightly modified -:

"I swear, by Apollo Physician, by Asklepios, by Hygieia (Health) and Panakeia, by all the gods and goddesses, making them my witnesses, that I will carry out, according to my ability and judgment, this oath, and this indenture. To hold my teacher in this art equal to my own parents; to make him partner in my livelihood; when he is in need of money to share mine with him; to consider his family as my own brothers and to teach them this art, if they want to learn it, without fee or indenture; to impart precepts, oral instructions and all other instruction to my own sons, the sons of my teacher and to indentured pupils who have taken the physician's oath, but to nobody else. I will use treatment to help the sick, according to my ability and judgment, but never with a view to injury and wrong-doing. Neither will I administer a poison to anybody when asked to do so, nor will I suggest such a course. Similarly I will not give to a woman a pessary to cause abortion. But I will keep pure and holy both my life and my art. I will not use the knife, not even, verily, on sufferers from stone, but I will give place to such as are craftsmen therein. Into whatsoever houses I enter, I will enter to help the sick, and I will abstain from all intentional wrongdoing and harm, especially from abusing the bodies of man or woman, bond or free. And whatsoever I shall see or hear in the course of my profession, as well as outside my profession, in the intercourse with men, if it be what should not be published abroad, I will never divulge, holding such 
things to be holy secrets. Now if I carry out this oath and break it not, may I gain for ever reputation among all men for my life and for my art; but if I transgress it and forswear myself, may the opposite befall me".

This oath is a sign that the transmission of medical knowledge in Cos was extended to "outsiders" at the time of Hippocrates and, for centuries, made of this island a reference for medical care, building the basis for medical deontology. Hippocrates left Cos but his son-in-law Polybios continued to practice and the Hippocratic school lasted until the Roman period.

One of the reasons for this reputation, is what modern scholars call the Hippocratic Corpus: about seventy treatises on ancient medicine written in the Ionic dialect. They deal with internal diseases, surgery and gynecology and they offer rational physiological as well as pathological theories. The surgical therapy of dislocations and fractures is often quite modern. For internal diseases, a treatment based on healthy habits (from diaitè "way of life, regimen") stands in the foreground.

Hippocrates himself is, of course, not the only author of all these volumes and most of the texts were written by his disciples long after his death and gathered together under the general authorship of Hippocrates. This corpus is very rich and diverse. Scholars consider that, if some of the books were written at the end of the fifth century or at the beginning of the fourth, others were composed as late as the second century AD. Some of the treatises, for example Fleshes or Regimen are deeply influenced by philosophical writings. One important fact should be pointed out; some of the most ancient treatises, of the time of Hippocrates himself or of his direct pupils, consider medicine as a science, detached from religion as well as from philosophy, and give the main part to scientific observation. This is why they are considered as giving birth to medical science, or to medicine as a science (Temkin, p. 213-225).

The medical literature of the subsequent 400 years has been lost. The center of medical thinking moved from Cos and Cnidus to Alexandria and Rome; two great Alexandrian physicians of the early third century, Herophilus and Erasistratus, continued the research of the dogmatic school, which soon was rivalled by the new empirical sect that banished the search for hidden causes and referred the physician to experience and analogical reasoning in unprecedented cases. In Rome a new sect appeared: the methodists, opposing the dogmatists' scientific theories as well as the empiricists' trust in experience. They stressed what is common in diseases, considering the laxity and tenseness of the body as well as the cycles in the rhythms of the body and advocated a methodical treatment (astringents or laxatives) to restore the balance.

Dioscorides' herbal, De Materia Medica, some works by Rufus of Ephesos and by the methodist Soranos, also from Ephesos, all practitioners from the first centuries AD, still exist. Aretaeus the Cappadocian probably also wrote at that time. Then, of course, the wealth of the Galenic writings of the second century AD, allows us an insight into the medical practices of this scientifically creative century. Galen (130-200), born in Pergamon, was a careful anatomist as well as a pathologist and a true heir of the Hippocratic medicine that he discusses in length. His work, 22 volumes, representing only two-thirds of what he wrote, 
was edited in the nineteenth century (1821-1833) with a Latin translation by G.C. Kühn. Galen travelled a lot. He went to Rome where he practiced and held public conferences on anatomy with dissections of animals, such as monkeys, pigs or even an elephant.

After Galen, medical thinking fell into the "darker ages". "Centuries passed. The Roman Empire broke up. The flame of Greek medicine flickered, but never died out. Three times, it was revived. The first revival occurred in Persia, between the fifth and tenth centuries" (Majno, p. 420), which explains why some Greek works have come down to us ultimately as Latin versions from Arabic texts translated from the Syriac. The second revival took place in Europe, when the printing press first made the texts more easily available, the third, in the 18th century, when Emile Littré translated the entire work of Hippocrates into French, over a twenty-two year period. As a result, Hippocrates, assumed his still current position as a central figure of Greek medicine.

However, he was, of course, not the only physician to help his fellow citizens. The handbooks of Greek literature are replete with references to doctors and medicine. Apart from the medical texts such as the Hippocratic Corpus or the others already mentioned, the Greeks often wrote about their physicians. Plato uses them in his comparisons, for instance, in the famous analogy stating that law is to gymnastics what justice is to medicine (Gorgias, 464B). However, he does not allude to any physician in particular, with the exception of Hippocrates.

Aristophanes generally gives a rather bad image of the physician, saying for instance that all doctors are interested only in how much they will be paid, "No fees, no doctor" (Ploutos, 407-8). Historians of the period do not usually mention physicians although a few names occur in Herodotus or Plutarch. The former writes of Democedes of Crotonia who was attached to King Darius' family and healed both him and Queen Atossa (III, 125 sqq.).

Inscriptions serve as a vital source of information concerning the everyday physician and ancient medicine. Epigraphy does not provide any information relative to the organization of studies, or precise treatments or on how to practice surgery, but different types of inscriptions give, here and there, some details about a physician's daily life.

Inscriptions mentioning the medical professions are numerous and, above all, varied, such as epitaphs, i.e. funerary inscriptions, dedications to gods or to physicians, decrees, lists and catalogs of different kinds. The origin of these inscriptions is quite varied. They have been found all over the Greek World which includes not only Greece and the Islands, but also Asia Minor, the Eastern Mediterranean, Africa, Italy and the West. A wide chronological period corresponds to this great spatial extension.

Physicians are mentioned in Greek in engravings on stones dating from the sixth century BC to the sixth century AD. One of the most ancient testimonies is a statue, a 1.19 m. tall marble kouros, from about 550 BC found in Megara Hyblaea in Sicily (Dubois, p. 28). It is now in the Museo Archaeologico of Syracuse. Unfortunately the statue is headless but the inscription, on his right thigh, can be read without any problem; it is engraved from the top to the bottom, but backwards and says "Somrotida to hiatro to Mandrokleous", meaning "[I am the monument] of Somrotidas, physician, son of Mandrokles". Considering the two names, the origin of his family was probably Ionian. Sombrotidas means "descendant of men's saviour" which perhaps indicates that his name was based on a family tradi- 
tion of medicine or on his profession... At any rate, he must have been a very important man to have been offered such a big statue. It is probable that the city granted him the kouros in gratitude for his medical services.

Even during Roman times, Latin-speaking authors like Sextus Niger or Julius Bassus made an effort to write in Greek on medical topics. Medecine was considered a Greek science, therefore, any professional who wanted to establish an evident link between himself/herself and the great Hippocrates used his language - even sometimes the specific Ionic dialect in which the Hippocratic Corpus is written! As far as epitaphs are concerned, the family emphasized the medical competence of the deceased by using this noble language. It is also important to note that very many physicians had Greek names; either they were of Greek origin, or they wanted their name to sound Greek in order to seem more competent. Two dedications found in Chester, the Roman Deva, now in Chester's Grosvenor Museum, engraved during the second century AD, serve as examples:

"To the all-mighty saviour gods, I, Hermogenes, physician, have consecrated this altar" (Collingwood, n. 461);

"Antiochos, the physician in honour to the eminent saviours of men among the immortals: to Asklepios with a healing hand, to Hygieia and Panakeia ..." (Wright, p. 285 n. 3).

These two physicians, possibly of Greek origin considering their names, were, it would seem, employed by the Roman army (the twentieth legio Valeria Vicrix was based in Deva). Although in Roman surroundings, they chose to have their dedication engraved in Greek and addressed to the healing gods listed in the same order as in the Hippocratic Oath $^{2}$.

A funerary stele from about $480 \mathrm{BC}$ represents a doctor, identifiable because of the cupping glasses which are placed on the ground near him (Berger, 1970). They are symbolic of the medical profession and are often found on bas relief related to doctors. The long stick which he is holding in his hand perhaps indicates that he was a travelling physician.

The term "medical profession" covers a relatively wide field: physicians iatroi, official or chief physicians archiatroi, women physicians iatrinai, archiatrinai (found on one stele), midwives maiai, "masseurs" iatraleiptai, and even veterinarians hippiatroi. The funerary stele of a woman named Mousa who lived in Byzantion during the second or the first century BC serves as an excellent example. The text reads "Mousa, daughter of Agathokles, physician (iatreine)" (Firatli-Robert p. 96 n. 139) ${ }^{3}$. She is represented on this bas-relief, carrying a roll. It is rare for a woman to be represented with this attribute; they generally are shown with mirrors, make-up accessories or objects referring to female occupations like a spinning wheel. So Mousa, the "intellectual", carries a sign of her sophia, to indicate that her knowledge was wide. She was learned in the medical art as well as in other arts, and this is reinforced by her name, probably a surname, based on the Muses; in other words, Mousa is familiar with all the arts. The two little dogs on the right symbolize her medical competence as this animal is associated with Asklepios. 
Jason (or Iason) practised in Athens during the second century AD (IG II/III 4513 \& Brit. Mus., Cat. Sculpt. 629). His epitaph says: "Jason, called also Decimos, from the deme of Acharnai, physician" and below, lists the other persons in the grave, his adopted son and son-in-law, Dionysios, his daughter Eirene, his grand-son Theomnestos and Theomnestos' wife Philostrate. Jason, a bearded figure, sits on a chair and examines the visibly ill naked patient standing in front of him. An enormous cupping glass on the right-hand side indicates without a doubt Jason's occupation, already stated by the inscription.

The material from which the stele was made and the extent of its embellishment are both silent witnesses to the social status of the members of the medical profession. As a matter of fact, in the Greek cities, slaves, freedmen and citizens could practice medicine, of course not with the same competence nor in the same conditions. In general, Greek physicians were free men, even if they did not practice in their native city. On the contrary, in the Western regions during the Roman Republic and the early Empire, physicians were often freedmen or slaves of foreign, and frequently Greek, origin. In the Eastern Provinces, on the other hand, numerous physicians belonged to very wealthy families during the 2 nd and 3rd century $\mathrm{AD}$, and formed a group of prominent citizens. These families often formed a type of medical dynasty which handled the training of future doctors as well as the healing of the sick.

In the "Golden years" of the genos of the Asclepiads, things were simpler. Knowledge was transmitted from father to son for generations. This continued to be the way of learning after the fifth century BC and spread beyond the genos of the Asclepiads. As the Hippocratic Corpus states, in the Law "He who is going truly to acquire an understanding of medicine must enjoy natural ability, teaching, a suitable place, instruction from childhood, diligence, and time." (ii, ed. \& transl. H.S.W. Jones, LCL, 1981). Many inscriptions insist on this fact as well.

From the time of Hippocrates, physicians could learn from a master if they paid. A very long inscription found in 1905, but published only in 1991 (Pugliese Carratelli, p. 135 sqq.), provides the cursus of a Coan doctor, Onasandros, who, obviously, did not belong to a family of physicians:

"Considering that the physician Onasandros, son of Onesimos, has learnt his art from Antipater, son of Dioscouridas, and has gone with his master during the time when he was a public physician in our city and behaved properly towards everyone, and spontaneously offered the service of his art to those of the demotes (citizens of the deme) who asked for it; seeing that, promoted assistant, he gave, during many years, the evidence of his professionnal competence and of his exemplary life, sparing neither energy nor his own money to help many of the demotes; seeing that, when his master was chosen for the public service of the city of Cos, Onasandros decided to collaborate too, first in assisting his master and then in helping personnally all the demotes who came to ask him, because they knew his professional competence and his attitude towards them, and he healed many of them. Seeing that he decided afterwards to open a center for medical 
care of his own and to offer private surgery, some of his patients helped him financially but - although he could have done it, regarding the favors he had done to them, how serious were the illnesses he had cured and with what exceptional remedies - he didn't ask any of the demotes to lend him some money, though he could have gathered a considerable capital. [...]"

The inscription goes on underlining how disinterested Onasandros remained during all those years. What is important to note is the progression in this text between the simple pupil (mathetes) of a master (didaskalos) and the assistant (huperetes), who already has some responsibility and may take some initiative in the treatment he prescribes. The pupils chose the master they wanted to learn from according to his reputation. Since no diplomas existed, the only way of getting serious qualifications and ultimately having a brilliant career, was to follow a good master. His name served as a guarantee for the patients and may have helped as a recommandation in getting the coveted official jobs. During the Hellenistic period (Jaeger, 1944), some cities possessed what could be called medical centers where the students could learn from different teachers gathered in places like the Mouseion in Ephesos or in Alexandria (Fraser, 1972).

Three options were therefore open to those who wished to learn the medical art (iatrikè technè): learning in the family, with a master, or in a school. The inscriptions show the different possibilities, for instance, young Orestes, from a wealthy family living in the Pisidian Adada during the second century AD, went to study in Alexandria where he unfortunately died in obscure circumstances (IGRR III, 374). After their studies, the physicians had to settle down in a city and establish a clientele. The period of learning was not fixed. Some sources indicate that it lasted as long as 4 or 5 years, which make the following resume of an epitaph all the more startling: Asiaticus, who died in Xanthos (Lycia) in the first or second century AD, aged 18, was already recognized as a "wise physician" (TAM II, 369). Either he began his studies at an extremely tender age or he completed them in less than four years.

During the Classical and the Hellenistic period, Greek physicians travelled a great deal. Some of them died more than a thousand kilometers from their native country; most of them practised in foreign towns. One of the treatises of the Hippocratic Collection, Airs, Waters, Places notes for the newly arrived physician what should be noticed concerning the geographic situation and the climate in order to help the physician in his first weeks of practice (Jouanna, 1996, introd.). The length of time that physicians chose to stay in a town was entirely up to them. Some stayed for a short while, and others for longer periods. Menocritos of Samos, for example, stayed on the small island of Karpathos for twenty years. Others were called to and by the cities in case of epidemics or wars, when the need for physicians was urgent. Hermias, a famous physician from Cos, is mentioned in three inscriptions: two from Creta, Cnossos and Gortys, and one from Halicarnassos. He helped the people of Cnossos during a "civil war" (219-217) where many were wounded. Thanks to his efficient competence, he saved a lot of men which is why the citizens of Cnossos voted a decree honouring Hermias in their assembly and sent a copy of it to Cos, where it was found (Syll. 528). Hermias is the only known physician whose medical skills were thus recognized on three separate occasions by three different cities. 
As there is no concrete evidence of the existence of hospitals at this time in the Greek cities, it seems logical to conclude that either the physician went directly to visit the sick in their home or received them in his office, the iatreion. The latter is depicted on a small fifth century vase, called aryballos where a doctor is beginning a blood-letting on his patient's right $\mathrm{arm}^{4}$. A container placed on the floor is to receive the blood. The presence of the cupping glass on the wall serves as an ultimate proof that this is indeed a doctor's office.

The iatreion (described in two treatises of the Hippocratic Corpus: The Physician and the Physician's office) was generally composed of two or three rooms. The presence of the physician, his assistants, the patients, the family and the public made these iatreia into crowded places. One room was used to receive the patients and the other(s) to keep the instruments, and the ingredients for drugs and eventually, to perform some surgery, with a bed to keep the wounded for a day or two. This place had to be sheltered from the wind, not too sunny, and yet, bright. The physician, says the Hippocratic text Peri Ietrou (The Physician), must be "clean in person, well dressed, and anointed with sweet-smelling unguents that are not in any way suspicious. This, in fact, is pleasing to patients." (ed. \& transl. H.W.S. Jones, LCL, 1981).

Concerning the fees, no inscription gives any precise indication. But they mention that some of the physicians healed their patients for free. One important characteristic of the Greek medical system was the existence of public physicians (Cohn Haft, 1956). These were hired by a city after an interview before the demos, in the Assembly, for a one year contract that could be renewed. During the audition, the physician was supposed to explain where and from whom he had learned his art, eventually present some witnesses (mainly healed patients), or letters of recommandation from other cities. To get this highly sought after job, some physicians offered to treat their patients without pay for a certain time, for example, six months. The public physician was paid by the city to take care of the population; the salary he received was probably variable, depending on the need, the number of candidates for the job and the reputation of the aspirant. Herodotus reports that the famous Democedes of Croton, installed in Egina, was paid one talent (i.e. 6000 drachmai) during his first year as a public physician; the year after, the Athenians sought him and offered him a hundred mines (10000 drachmai) and the third year, Polycratos of Samos hired him for two talents (Herodotus, III, 131). Concerning salaries, misthoi, inscriptions are very discreet. The only mention is on an old tablet found in Idalion (Masson, p. 235-344, n. 61), Cyprus, presenting the contract between king Onasikypros and the physician Onasilos and his brothers, according to which they would receive one talent and take care without additional payment of all the wounded in the war (478-470). In any case, this official salary did not hinder the physician from accepting a voluntary reward by satisfied patients if they so wished! With the money he received from the city, the public physician was supposed to pay for the manufacture of instruments, the rent of the iatreion and the preparation of drugs and remedies. Such surgical and medical instruments have both been pictured on stone and found by archaelogists in various graves. To pay the public physician, the cities raised a special tax, called iatrikon, that the citizens and probably the metoikoi were supposed to pay.

If the physician, public or private, had helped the city, an honorary decree was voted to honour him. In this official text, voted by the Assembly, the merits and the good deeds of the physician towards the city and the inhabitants were proclaimed in very general and conventional terms. The honorary decree for the physician Asclepiades, found in 1914 in 
Antalya on the Turkish coast summarizes what was expected of a good doctor in Hellenistic times (Merkelbach \& Sahin, p. 104 n. 5):

"It pleased the Boule and the Assembly. Seeing that Asklepiades, son of Myron, from Pergè (Pamphylia) our famous citizen who practices the medical art, has given many proofs of his competence, and during conferences that he gave in the gymnasium, he exposed to his fellow citizens a lot of useful questions concerning health; and he paid to his patients an attention worthy of himself and of his ancestors, and he has adopted a decent, honorable behaviour, fitting with his profession; having travelled abroad, he has accomplished many deeds for his honour and reputation and has brought forward the testimonies of the cities as decrees, or official letters about the honours he received. May it please the assembly: to praise publicly Asklepiades for this and for his good repute, to give him a copy of this decree, certified by the public seal".

Another text from the city of Seleukeia repeats almost the same praise. The physician is honoured for several reasons: first of all, because he was a good practitioner and paid attention to his patients; secondly he tried to inform his fellow citizens about the importance of prophylactic treatments, and thirdly, he adopted an "honorable behaviour, fitting with his profession". This last point is mentioned very often in the inscriptions, thus calling attention to its importance. This is a clear statement that the physician belonged to the kaloi kagathoi.

This brief glimpse of ancient Greek medicine provides an modest image of the role of both divine and human intervention; if Asklepios played his part throughout the centuries, men and women, with their own competence, tried to help their neighbour, accomplishing in that way the purpose expressed in the Hippocratic treaty The Art (Peri technès), "in general terms, medicine is to do away with the sufferings of the sick and to lessen the violence of their diseases..."

\section{Notes}

1 - Translations are mine, if not otherwise indicated. This article was written after a paper presented at Leicester University, where I was invited by Dr Nicholas Davidson. I thank Dr. Gloria Russo for keeping a watchful eye on my English and Dr. Silvia Milanezi for introducing me to Classica.

2 - This attitude is comparable to the way French doctors in the XVIIth century used Latin among themselves, although the population didn't speak Latin any longer. The renowned author Molière mocked this in some of his comedies, insinuating that it was just a trick to impress the patients and hide the physicians' ignorance.

3 - She is one of the 15 women explicitely designated as physician (and not midwives) out of the 552 inscriptions I collected (to be published in Paris in 2002).

4 - Aryballos Peytel, Paris, Musée du Louvre (inv. CA 2183), ca 470 BC. Cf. Jouanna, 1995, p. 124 sqq. 


\section{Abbreviations}

Berger

Cohn-Haft

Collingwood

Dubois

Firatli-Robert

Fraser

Herzog,

Jaeger

Jouanna

Majno

Masson

BERGER, Ernst. Das Basler Arztrelief. Basel: Archäologischer Verlag, 1970.

COHN-HAFT, Louis. The Public Physicians of Ancient Greece. Northampton Massachussets: Smith College Studies in History, 1956 COLLINGWOOD, R. G. \& WRIGHT, R.P. Roman Inscriptions of Britain. I, Oxford, 1965.

DUBOIS, Laurent. Les inscriptions grecques dialectales de Sicile. Rome: EFR, 1989.

FIRATLI, Nezih \& ROBERT, Louis. Stèles funéraires de Byzance gréco-romaine. Paris: De Boccard, 1964.

FRASER, Peter M. Ptolemaic Alexandria. Oxford: Oxford University Press, 1972.

HERZOG, Rudolf. "Die Wunderheilungen von Epidauros". Philologus, Suppl. xxii, Heft iii, Leipzig, 1931

JAEGER, Werner. Paideia. III, New York-Oxford: Oxford University Press, 1944, chap.1.

Hippocrate. Airs, Eaux, Lieux. éd. JOUANNA Jacques, Paris: Belles Lettres CUF, 1996.

MAJNO, Guido. The Healing Hand. Man and Wound in the Ancient World.Harvard: Harvard Univ. Press, 1991.

MASSON, Olivier. Inscriptions chypriotes syllabiques, Paris: De Boccard, 1961.

Merkelbach \& Sahin MERKELBACH, Reihold \& SAHIN Sencer. Epigraphica Anatolica 11 (1988).

Peek PEEK, Werner. Sitzungen der Preussischen Akademie der Wissenschaften zu Berlin, 1963.

Pugliese-Carratelli, PUGLIESE CARRATELLI, Giovanni. Parola del Passato, 46 (1991), p. 135-140.

Temkin TEMKIN, Owsei. "Greek Medicine as Science and Craft", Isis 44 (1953), p.213-225.

Varinlioglou VARINLIOGLOU, E. Epigraphica Anatolica 12 (1989), p.42-43.

Wright

WRIGHT, R. P. JRS 59 (1969), p. 285.

\section{Bibliography}

\section{Asklepios}

BURFORD, Alison. The Greek Temple Builders at Epidauros. Liverpool: Liverpool Univ. Press, 1969 
EDELSTEIN, Emma J. \& Ludwig. Asclepius: a collection and interpretation of the testimonies. 2 vols., Baltimore, Johns Hopkins Press, 1945.

KRUG, Antje. Heilkunst und Heilkult: Medizin in der Antike. Munich, 1985

LI DONNICI, Lynn R. The Epidaurian Miracle Inscriptions. Atlanta, 1995.

\section{Greek medicine and physicians:}

ANRW II, 37, 2: several contributions on Galen

ANDRÉ, Jacques. Etre médecin à Roma. Paris: Belles Lettres, 1987.

BRANDENBURG, Dietrich. Medizinisches bei Herodot. 1976.

COHN-HAFT, Louis. The Public Physicians of Ancient Greece. Northampton Massachussets: Smith College Studies in History, 1956.

CORDES, Peter. Iatros, das Bild des Arztes in der griechischen Literatur. Stuttgart: Steiner, 1994.

DEICHGRÄBER, Kar. Medicus gratiosus. Mainz, 1970.

GOUREVITCH, Danielle. Le triangle hippocratique dans le monde gréco-romain. Rome: BEFAR, 1984.

GRMEK, Mirko D. (ed.). Histoire de la pensée médicale en Occiden. Paris: Seuil, 1995.

JACKSON, Ralph. Doctors and Diseases in the Roman Empire. London: British Museum Press, 1988.

JOUANNA, Jacques. Hippocrate. Paris: Fayard, 1995.

KOELBING, Huldrych M. Arzt und Patient in der antiken Welt. Zürich \& Munich: Artemis Verlag 1977.

KOLLESCH, Jutta; NICKEL, Diethard (edd.). Galen und das Hellenistische Erbe. Stuttgart: Steiner, 1993.

KUDLIEN, Fridolf. Die Sklaven in der griechischen Medizin der klassischen und hellenistischen Zeit. Wiesbaden: Steiner, 1968.

. Der griechische Arzt im Zeitalter des Hellenismus. Mainz: Akad. der Wiss. u. Literatur, 1979.

Die Stellung des Arztes in der römischen Gesellschaft. Stuttgart: Steiner, 1986.

MUDRY, Philippe \& PIGEAUD, Jackie (edd.). Les écoles médicales à Rome. Lausanne, 1991.

MÜRI, Walter (ed.). Der Arzt im Altertum. Munich, 1962.

NUTTON, Vivian. From Democedes to Harvey. London: Variorum Reprints, 1985

In CONRAD, Lawrence I.; NEVE, Michael; NUTTON, Vivian; PORTER, Roy; WEAR, Andrew (edd.). The Western Medical Tradition, 800 BC to AD 1800. Cambridge: Cambridge Univ. Press, 1996, chap. 1.

VAN BROCK, Nadia. Recherches sur le vocabulaire médical du grec ancien. Paris: Klincksieck, 1961.

VON STADEN, Heinrich. Herophilus: the Art of Medicine in Early Alexandria. Cambridge: Cambridge Univ. Press, 1989. 
SAMAMA, E. Asklepios, Hippocrates and their followers: some aspects of healing and physicians in the Ancient World. Classica, São Paulo, 13/14, p. 301-314, 2000/2001.

ABSTRACT: This paper deals, in a very general perspective, with the relationship between religious medicine and the everyday task of physicians in the Greek world, paying attention not only to some of the medical texts but mainly to the epigraphical evidences.

KEYWORDS: Greek medicine; epigraphical sources. 